\title{
Wage-setting Behavior in France: Additional Evidence from an Ad-hoc Survey
}

\author{
Jérémi Montornès ${ }^{1}$ \\ Banque de France, France \\ jeremi.montornes@banque-france.fr \\ Jacques-Bernard Sauner-Leroy \\ IEFP, France \\ jb.sauner-leroy@lafinancepourtous.com
}

\begin{abstract}
We investigate the wage-setting behavior of French companies using an ad-hoc survey specifically conducted for this study. Our main results are the following. i) Wages are changed infrequently. $75 \%$ of firms change their wages once a year. Wage changes occur at regular intervals during the year and are concentrated in January and July. ii) We find a lower degree of downward real wage rigidity and nominal wage rigidity in France compared to the European average. iii) About one third of companies have an internal policy to grant wage increases according to inflation. iv) When companies are faced with adverse shocks, the latter are partially transmitted into prices. Companies also adopt cost-cutting strategies. The wage of newly hired employees plays an important role in this adjustment.
\end{abstract}

\section{JEL classification: E24, J3}

Keywords: wage rigidity, wage-setting behavior, survey data.

\section{INTRODUCTION}

The existence and the extent of wage rigidities have crucial implications for monetary policy analysis. First, a high degree of wage indexing (i.e. real rigidities) can generate a self-sustaining rise of inflation following a sectoral shock of inflation via second-round effects. Second, the extent of nominal rigidities affects the definition of the inflation target. The downward rigidity of nominal wages requires a certain level of inflation to allow real wages to adjust to changing conditions greasing the wheels of the labor market (see Tobin, 1972). Despite the importance of the issues at stake, there is still no consensus on both theoretical mechanisms underlying wage rigidities and empirical assessment of the extent of wage rigidities.

\footnotetext{
Corresponding author. Jérémi Montornès, Banque de France, 31 rue Croix-des-petits-champs, 75049 Paris Cedex 01, France, e-mail: jeremi. montornes@banque-france.fr, telephone: +33.1.42.92.49.27, fax: +33.1.42.92.27.09.
} 
More generally, in macro models wage rigidities imply real and persistent effects of monetary shocks on output (Christiano et al., 2005). New Keynesian models assume that a firm will change its wages randomly (Erceg et al., 2000; Smets and Wouters, 2003). In each period, a fraction of wage contracts is not reoptimized and is partially indexed to past inflation. The Calvo parameter is typically found to be consistent with duration of wage contracts of 3 or 4 quarters (see e.g. Gertler et al., 2008). This degree of wage rigidity allows replicating the wage dynamics in macroeconomic models but the nature of the rigidity can also play a crucial role. For instance, Levin et al. (2005) show that the different models used to represent wage rigidity at the micro level may lead to modifications in the optimal monetary policy but also in welfare losses. Apart from the Calvo model, a less frequently used one is the Taylor contract model where wages are set for a constant duration. Recently several contributions underlined the role of downward wage rigidity in the context of the debate of the appropriate inflation target for central banks. Kim and Ruge-Murcia $(2009,2011)$ introduce a cost of adjustment in the wage setting function (i.e. wage adjustment costs are asymmetric and larger for downward than upward wage changes). MacCallum and Smets (2010), Schmitt-Grohé and Uribe (2013) analyze the consequences of downward wage rigidity for the Eurozone in the context of the Great Recession.

The theoretical literature has identified different mechanisms of wage rigidities (see Cahuc and Zylberberg, 2004, for a comprehensive presentation of wage formation models). The first branch focuses on the role of unions and bargaining power in generating rigid wages. In these models, the rent generated by the firm guarantees insiders bargaining power in wage negotiations. In this context, the extent of rigidity is linked to the magnitude of unions' bargaining power. The second source of rigidity identified in the literature stems from the incentive for managers to pay their employees more than the market-clearing wage. The key assumption of these models is that high wages make workers more productive. Several versions of the 'efficient wages' hypothesis have been formulated, including shirking, fairness, turnover and adverse selection mechanisms. All these models imply downward wage rigidity despite any excess of labor supply. However, empirical studies do not easily allow alternative models supporting the existence of wage stickiness to be distinguished. Econometric tests of various theories of wage rigidities fail because of the lack of variables especially designed for the purpose of the analysis. For instance, efficient-wage theories often rely on non-traditional variables for economists such as fairness, effort or reciprocity in labor relations. In addition, it is hard to discriminate empirically among theories according to their predictions since they all predict wage rigidity.

The empirics of wage rigidity focus rather on the extent of rigidity than on the causes of downward rigidity. Most evidence produced on downward wage rigidity has been motivated by the debate on the appropriate inflation target for central banks (see Akerlof et al., 1996) and recently to feed the calibration of macro models (Barraterri et al., 2014). Empirical studies typically adopt statistical models of wage change distribution rather than a structural model inspired by theory. Direct evidence of downward nominal wage rigidity comes from cross-sectional analysis of the distribution of wage changes which almost always shows a spike at zero and a positive skew (Card and Hyslop, 1997; Lebow et al., 2003). However, this 'histogram-location' approach is subject to measurement errors. Altonji and Devereux (2000) provide an econometric analysis dealing explicitly with measurement errors and allowing individual heterogeneity. The International Wage Flexibility Project (IWFP) has provided a unified framework of analysis for 16 OECD countries. However, results on the extent of wage rigidities vary a lot according to the country (especially in Europe), the period under review (especially because of the influence of the inflation rate) and the data used (see Dickens et al, 2007 and the special feature of the Economic Journal in 2007).

A special line of research consists in exploiting qualitative surveys among firms' managers (see Blinder and Choi, 1990) collecting both additional evidence and perceived explanations of wage stickiness. Blinder's work has been replicated in the United States and has inspired similar research in other countries. Campbell and Kamlani (1997) highlighted the practise of efficiency 
wage as a factor of wage stickiness for the United States. Bewley (1999) also enhances the psychological factor of morale to explain downward wage rigidity. This contrasts with European countries. For instance, Franz and Pfeiffer (2006) highlight the role of implicit and explicit contracts in Germany. Agell and Bennmarker (2005), Zoega and Karlssonn (2005) also stress the importance of legislation on wage formation in Sweden and Iceland.

Previous works on wage rigidities in France were based on quantitative sources (Biscourp et al., 2005; Le Bihan et al., 2012). By contrast, this study uses new qualitative information on wage setting in France based on an original survey conducted among two thousand firms of the market sector representing approximately 500,000 employees (see Appendix 1). The survey ${ }^{2}$ has been undertaken as part of the Wage Dynamics Network ${ }^{3}$ (WDN). We replicate the methodology proposed by Blinder at a larger scale. First, the WDN survey is based on a large and nationally representative sample. Second, it collects additional evidence on wage setting and information about the firms' economic and institutional environment that are seldom available. In particular, the data collected help in testing indicators of the strictness of wage setting institutions or perceived competition from the point of view of firms.

The paper aims at providing new evidence on the extent and reasons behind different types of wage rigidity. The latter is defined as the frequency of wage changes and the ability to adjust to shocks. This definition of wage rigidity is thus broader than the one used in the empirical literature which generally focuses on downward wage rigidity. Second, the WDN Survey gives insights into the relative importance of nominal versus real rigidities. We also attempt to establish some of the reasons for wage rigidity. However, the contribution of the paper lies in how firms adjust to shocks. It analyses not just wage rigidity but also adjustment of firms in the presence of downward wage rigidity. The adjustment process relates to firms' responses to different kinds of adverse shocks including alternative means: change in prices, output, costs and profit margin. When companies are faced with adverse shocks, only a partial response is transmitted into prices. Companies also adopt cost-cutting strategies.

The paper is organized as follows. Section 2 presents the survey. Section 3 reviews the main characteristics of the French wage setting procedures. Sections 4 examines the patterns of wage setting and section 5 investigates downward wage rigidity. Section 6 is devoted to reactions to shocks. Section 7 concludes.

\section{DATA DESCRIPTION}

The WDN survey is a one-off survey conducted in 2007 that aims at investigating wage policies of human resources managers. The questionnaire refers to the main socio-occupational group within firm ${ }^{4}$ (in each firm the main group accounts for $67.9 \%$ of the employees on average). Thus, this survey strongly differs from traditional sources (administrative data or household survey) that collect individual records of wages. Typically, the survey aims at providing answers in a qualitative way to the following questions: How often do base wages change? Do the changes take place in specific months of the year? Respondents were also asked to assess the relevance of prices, margins, output or costs reductions in response to three unanticipated changes in their business environment: a slowdown in demand, an increase in the cost of an intermediate input (e.g. an oil price increase), and an increase in wages due to contracts bargained at the industry

\footnotetext{
The survey was conducted among a sample of companies usually interviewed for the purpose of the Banque de France's monthly Business Survey that comprises around 6600 firms (see details in Appendix 1). An electronic template of the questionnaire is available upon request.

3 The Wage Dynamics Network involves National Central Bank of 16 countries in Europe and has been coordinated by the Eurosystem.

4 This does not include individualized wage increases.
} 
level. The use of 'stated-preference'5 data to investigate companies' wage setting behavior has several advantages for our purpose.

First, ad-hoc surveys allow collecting information on variables of interest that are seldom available, such as perceived reasons for downward wage rigidity or response to shocks. Moreover, the survey is more likely to provide relevant information on how firms deal with laws or institutions than objective data (e.g. national indicators of bargaining coverage). Second, direct questioning may help address the econometric issue of identifying idiosyncratic shocks. As firms are asked to indicate how they respond to shocks, there is no need to identify the shocks themselves. Finally, as both the sampling frame and the concept of wages are similar across countries participating in the WDN project, our data makes fully homogeneous comparisons between numerous European countries 6 possible. A follow-up was conducted in 2009 by the Banque de France (on a partially renewed sample and a targeted questionnaire on answer to shocks) and other European countries to assess the impact of the 2008 recession on wages. By contrast to the first round of the survey where shocks were hypothetical, the second round of the survey took place in a context of a severe recession. The results of this follow-up round confirm that French firms responded to the marked drop in their sales by adopting strategies combining cuts in production and in labor costs. As in the first round of the survey, French firms answered they adjusted their wage bills by reducing variable components of compensation and the number of hours worked, but above all by cutting the number of temporary and permanent jobs.

There are, of course, limitations to the data we use. This ad-hoc survey is cross-sectional by nature. Moreover, some questions might be misunderstood because they do not match the specific context of the firm. Respondents may focus more on nominal rigidities rather than on real rigidities because they can be affected by monetary illusion. Furthermore, responses also have to be treated with caution because the person who filled in the questionnaire might not be aware of the entire wage-setting process, especially in large firms (e.g. profit-sharing scheme). However, international comparisons (Druant et al., 2012) exhibit robust stylized facts across countries. Wage setting characteristics such as the frequency of wage changes is shown not to be very different across European countries. Thus, WDN surveys represent a complementary data set and a useful crosscheck of the evidence obtained from quantitative sources.

Respondents were asked to provide information on the way they behave under normal conditions and practises. Quantitative information relates to the previous accounting year. Thus, their responses depend, among other things, on the economic situation in France at the time the survey was conducted. It took place in an environment characterized by persistent unemployment and low inflation. The unemployment rate $(7.9 \%)$ has been on a downward trend since mid-2004 but it still remains higher than the European average. In 2007, the consumer price index grew at a rate of two percent, broadly stable compared to the preceding year. Economic growth in the first half of 2007 was in line with potential output.

The descriptive results are weighted in order to take into account the size of the firm and the probability of sampling ${ }^{7}$ (see Appendix 1). This procedure, communally used in surveys, makes the descriptive results representative of the whole economy. Table 1 gives a general picture of company characteristics in France. Hiring and firing are positively correlated across sectors and appear to be lower in the manufacturing sector and in larger companies. Companies hire employees mostly on fixed-term contracts or have recourse to temporary work. However, the

5 In numerous questions of the WDN survey (response to shocks, deviation from the on-going wage, etc.), the respondent is asked to choose an answer from among different propositions. 'Stated-preference' data contrasts with 'revealed-preference' data that relates to people actual choices in real situations.

Cross-countries studies exploiting the European harmonized sample: Fabiani et al. (2012) examine linkings between wages and prices decisions, Babecky et al. (2012) assess downward nominal rigidities, Bertola et al. (2012) investigate the wages response to shocks, Galusak et al. (2012) focus on the issue of new hires wages. Similar surveys, using the WDN questionnaire, have also been conducted in Japan (see Ariga and Kamabayashi, 2010) and in Canada (see Amirault, Fenton and Laflèche, 2013).

The sample composition overrepresents the manufacturing sector compared to the service sector (especially compared to non-market services that comprise only 18 companies). 
number of these contracts remains limited (10\% of the national workforce). The vast majority (more than 90\%) of contracts are permanent full-time ones.

Table 1

Company characteristics (in \%)

\begin{tabular}{|c|c|c|c|c|c|c|c|c|c|c|c|}
\hline & \multirow{2}{*}{$\begin{array}{c}\text { Labor } \\
\text { Cost Share }\end{array}$} & \multicolumn{4}{|c|}{ Main socio occupational group } & \multicolumn{3}{|c|}{ Types of Workers } & \multirow{2}{*}{$\begin{array}{l}\text { Export } \\
\text { share }\end{array}$} & \multicolumn{2}{|c|}{ Labor mobility } \\
\hline & & Production & Technical & Clerical & Professional & Full time & Part-time & Temporary & & Entry & Exit \\
\hline Total & 39.0 & 47.8 & 22.3 & 10.7 & 19.2 & 85.7 & 8.6 & 5.7 & 16.2 & 15.5 & 16.7 \\
\hline \multicolumn{12}{|l|}{ By sector } \\
\hline Manufacturing & 28.2 & 58.3 & 15.9 & 12.7 & 13.1 & 92.2 & 3.9 & 3.9 & 27.2 & 10.8 & 10.1 \\
\hline Trade & 19.6 & 46.0 & 25.3 & 15.5 & 13.2 & 92.1 & 4.3 & 3.6 & 3.9 & 17.7 & 16.3 \\
\hline Business services & 49.6 & 39.7 & 26.6 & 8.6 & 25.1 & 79.5 & 13.2 & 7.3 & 7.8 & 18.9 & 21.8 \\
\hline Personal services & 57.6 & 6.4 & 74.5 & 6.2 & 12.9 & 82.6 & 6.7 & 10.7 & 0.0 & 55.4 & 63.3 \\
\hline
\end{tabular}

Note: 'Entry' and 'Exit' are measured in terms of the total workforce.

Source: WDN Survey.

\section{WAGE SETTING PROCEDURES IN FRANCE: AN OVERVIEW}

In this section, we review wage setting procedures to allow a better understanding of the empirical pattern of wage dynamics. Like in many countries in continental Europe, wage bargaining occurs at two levels. First, wages are defined by a multi-employer agreement (between employer associations and union or employee representatives). In addition, agreements might be improved by single-employer agreements at the company level ${ }^{8}$. Furthermore, the government indirectly intervenes via extension mechanisms of collective agreements (at the request of employers or unions). The Auroux law (1982) also requires annual negotiations both at the company and the industry levels.

At the industry level, employers have to bargain wage rates collectively when there are union representatives within the company. All companies are therefore not obligated to negotiate on wages but most are covered by an industry agreement. These agreements typically specify the wage scale for different tenure levels for a range of different job categories. At the bottom of the wage scale, the minimum wage equally applies to every industry and thus constitutes a national wage floor. To ensure fair competition, industry level agreements may be extended to all companies belonging to the sector after a governmental decision.

At the company level, initiating annual negotiations is compulsory but the 'social partners' are not obliged to reach any agreement. A firm-level agreement almost always improves the situation of employees in relation to the industry level agreement in force. If negotiations fail (in $20 \%$ of cases), the existing pay structure remains applicable. Overall, $98 \%$ of the firms of the sample are covered by collective agreements (either negotiated at the company- or the industrylevel) although union membership is lower than $10 \%$ of the workforce. There can be significant differences in coverage between sectors, size and geographical areas.

In France, an escape clause has existed since 2005 but it is rarely used by firms. 
Table 2

Collective agreements (in \%)

\begin{tabular}{lccc}
\hline \hline & Collective agreement Firms & Firm-specific wage policy & Wage drift $^{*}$ \\
\hline Total & 97.9 & 46.0 & 6.5 \\
By sector & & & \\
Manufacturing & 98.5 & 50.5 & 5.7 \\
Trade & 99.2 & 47.7 & 4.7 \\
Business services & 97.3 & 43.1 & 7.4 \\
Personal services & 98.4 & 1.6 & 1.0 \\
\hline \hline
\end{tabular}

Wage dift = "effective" wage - "bargained" wage (in level).

Source: WDN Survey.

Collective agreements might shape wage setting rules (see Section 4.3). Avouyi-Dovi et al. (2013) show that there is a strong seasonality in wage bargaining rounds: $50 \%$ of wage agreements are signed during the first month of the year. The duration of a collective agreement is typically 12 months. Occasionally, employers and employees' representatives find an agreement for a period of 24 months. Most agreements are strongly driven by developments in the price index. A majority of European countries share these characteristics (Du Caju et al., 2012).

However, agreements at industry level are not systematically binding and companies also have specific wage policies. Results taken from the survey indicate that actually paid wages are higher than negotiated wages in nearly half of the firms. These figures are broadly equivalent to those observed in Belgium for which this information is available (see Druant et al., 2012). The magnitude of the wage drift is also comparable with estimates for Spain based on a structural model (see Palenzuela and Jimeno, 1996). According to the WDN survey data, effective wages exceed tariff wages by about $6.5 \%$ (see Table 2). The size of the gap sheds light on the respective role of industry and firm negotiations. The wage drift tends to be higher in larger firms and in business services. This so-called 'wage drift' is likely to happen in heterogeneous sectors where sectoral bargained wages are low. Moreover, it can be in the interest of the firms to pay workers above the going rate set in the agreement. First, it might reflect pay policies by firm. One can argue it amplifies the effect of workers' characteristics on wages as assumed in efficient wage theories, especially in business services. Second, it could also reflect unions' wage premium and rent sharing, especially in large firms. Third, the gap between effective wages and tariff wages can be used to buffer possible and unwanted collective wage agreements since it allows employers to counterbalance increasing tariff wages. Then it can be interpreted as a short-term margin of flexibility for firms inside an industry coordinated wage bargaining system, especially for wages of newly hired employees. In this respect, a study panel data in Portugal also shows that the wage drift is contra-cyclical while wages are procyclical (Cardoso and Portugal, 2005).

\section{PATTERNS OF WAGE SETTING}

In this section, we aim at characterizing empirical wage-setting rules. In this respect, there are two elements of particular relevance: the frequency and the timing of wage changes.

\subsection{Frequency of wage changes}

In the survey, firms had to indicate the number of times they change their wages in a given year. Wages are found to be relatively rigid in the sense they are changed every year. $74 \%$ of 
companies change wages once a year ${ }^{9}$ (see Table 3 ). Nearly $20 \%$ of companies indicate they change the base wage more than once a year. The fraction of firms which do not change wages is negligible. The wage change frequency is higher than the Euro Area average (74\% in France vs. $60 \%$ in Euro Area, cf. Druant et al., 2012). Results for France are also consistent with Biscourp et al. (2005), who obtain a frequency of annual wage changes equal to $89 \%$. The frequency of wage changes varies across sectors. For instance, wages change more frequently in the trade sector. Wage changes are less frequent in services than in manufacturing.

Table 3

Wage change frequency (in \%)

\begin{tabular}{lcccc}
\hline \hline & $\begin{array}{c}\text { More frequently } \\
\text { than once a year }\end{array}$ & Yearly & $\begin{array}{c}\text { Less frequently } \\
\text { than once a year }\end{array}$ & Never \\
\hline Total & 19.5 & 74.3 & 5.2 & 1.1 \\
Manufacturing & 23.7 & 71.8 & 3.9 & 0.6 \\
Trade & 28.4 & 53.6 & 12.1 & 5.8 \\
Business services & 15.6 & 77.4 & 5.8 & 1.2 \\
Personal services & 0.0 & 93.5 & 6.5 & 0.0 \\
0-19 employees & 12.8 & 66.0 & 17.9 & 3.3 \\
$20-49$ employees & 13.6 & 76.7 & 8.8 & 0.9 \\
$50-199$ employees & 20.3 & 72.2 & 6.3 & 1.2 \\
$>200$ employees & 21.5 & 75.6 & 2.1 & 0.7 \\
\hline \hline
\end{tabular}

Source: WDN Survey.

\subsection{Timing of wage changes}

A heuristic distinction is traditionally made in macro models between state-dependent and time-dependent wage setting rules. First, there is state-dependence wage setting when companies change wages as a result of a large change in economic conditions. A standard justification for this type of adjustment is the prevalence of adjustment costs (in the wage setting context, it might be the cost of opening negotiations). Thus, firms following state-dependence rules change wages in response to shocks. Second, time-dependence wage setting applies when companies change wages on a periodic basis. The time interval of the nominal contracts is often modelled, e.g. by Taylor (1980), as fixed. Workers sign contracts that specify a fixed wage for several periods. The current generation of macro models also refers to Calvo-type contracts where the duration between two changes is random. Note that these state- and time-dependent rules are not mutually exclusive. Firms seem to change wages each year if their economic environment is stable but might renegotiate contracts in the presence of shocks (see Section 6).

Overall, our descriptive results suggest that the mean wage contract is one year and that a single simple Calvo model does not allow for replicating the wage dynamics at the micro level. The reason is that a significant proportion of firms also follow the Taylor model. Moreover, at the Euro Area level, the typical length of a wage contract varies according to countries (from 6 months up to 2 years).

\footnotetext{
9 Frequency is a synthetic variable based on three variables of the questionnaire: changes due to tenure, changes due to inflation and 'independent changes'.
} 
Figure 1

Timing of wage changes (in \%)

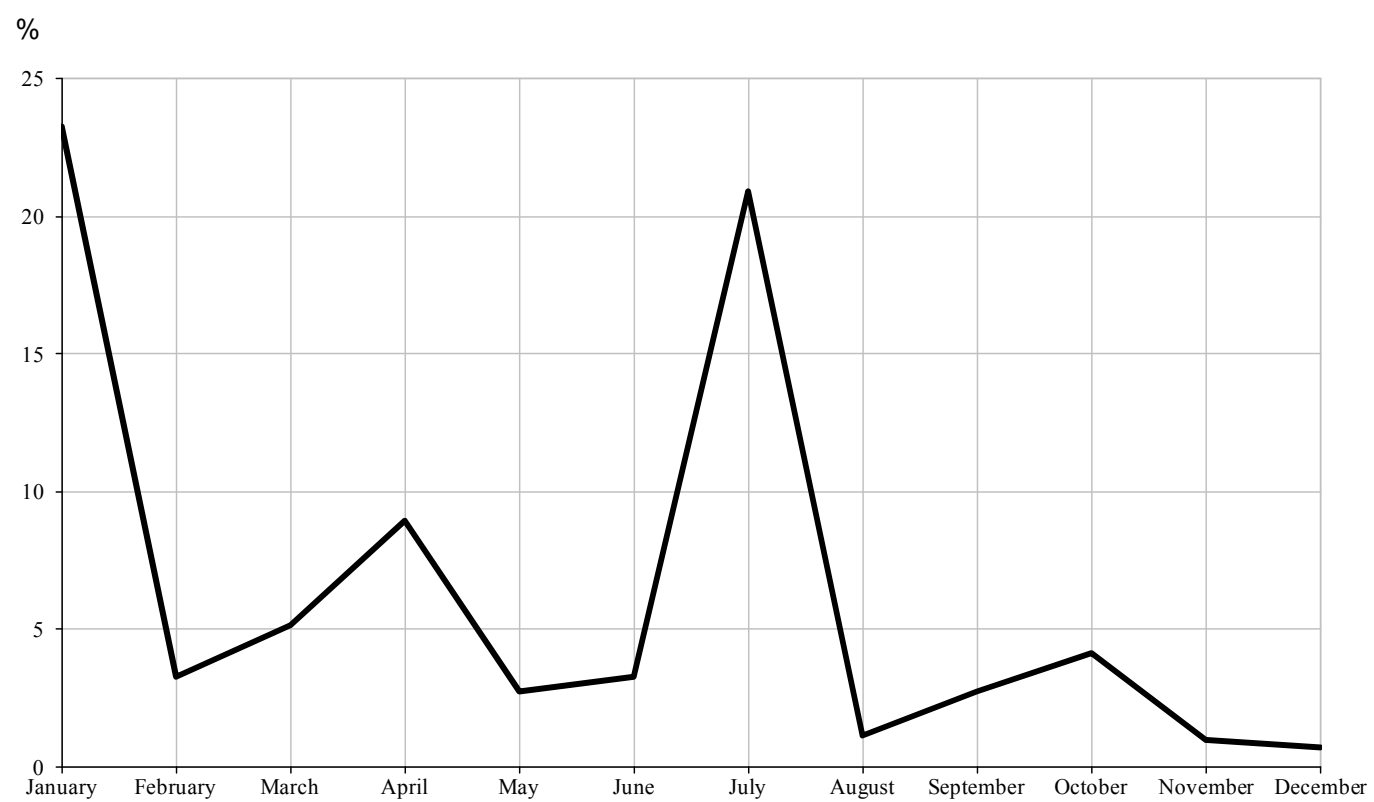

Source: WDN Survey.

Figure 1 plots the timing of wage changes by month. We find a strong seasonal pattern of wage changes decisions. Indeed, 58\% of firms change base wages in January or in July. Overall, 78\% of companies change wages in a particular month of the year. There is a clear synchronization in wage changes. However, it is difficult to determine whether this pattern provides evidence for state-dependence behavior (in response to the numerous price changes observed in January) or whether it reflects time-dependence due to institutional factors. The January effect might be due in large part to collective bargaining rounds, which take place at the beginning of the year (see Section 3). The July effect also results from the minimum wage increase. An important implication of wage staggering is that the impact of monetary policy shocks varies according to the period in which the shock takes place. In a VAR framework, the response of inflation is faster and larger if an interest rate change takes place in the quarter when most workers actually renegotiate. Olivei and Tenreyro (2010) argue that in the United States and Japan, a relatively large fraction of wage rates are re-contracted in the second half of the year. Thus, a monetary policy shock that occurs in the first or second quarter of a given year has a sizeable effect on output while this seasonal pattern plays a less important role in Germany, the United Kingdom and France. The ECB (2009) also confirms for the whole Euro Area that quantitative importance of wage staggering for inflation and output responses after a monetary policy shock is limited.

\section{DOWNWARD WAGE RIGIDITY}

In this section, we provide new evidence on the extent of downward wage rigidity. Standard measures of wage rigidities in the literature are based on year to year wage changes distributions of the same employees (see Kramarz, 2001, for a survey). Downward nominal wage rigidity (DNWR), that is resistance to cutting nominal wages, is usually identified by the extent of the spike at zero on the histogram of wage changes (i.e. the number of individual wages that remain unchanged). Downward real wage rigidity (DWRW), that is resistance to cutting real wages, is measured by the spike at the rate of inflation. Moreover asymmetries around zero are also considered as evidence of downward wage rigidity. However, the great majority of studies which 
intend to measure downward wage rigidity conclude that measurement errors are a serious problem (see e.g. Altonji and Devereux, 2000). The use of administrative datasets makes it difficult to properly identify base wage because of the inclusion of overtime hours and bonuses. If base wage levels are measured with errors, this leads to spurious wage changes that may wrongly be interpreted as wage flexibility. Furthermore, the use of household surveys may lead to an overestimation of wage rigidity since rounding effects bias wage changes toward zero. Changes in working conditions (e.g. a shift from a full-time job to a part-time status or a shift from night work to day work) may also add noise to the data.

WDN surveys avoid these methodological pitfalls. We take advantage of the fact that human resources managers are directly questioned on their wage policies. We indeed measure deliberate wage changes that are indicated by respondents. Downward nominal wage rigidity is computed as the share of nominal wage freezes. The WDN survey does not include a direct proxy of downward real wage rigidity. We use the proportion of firms linking wages to past inflation as a proxy to define it. This includes firms that are constrained from adjusting real wages not only downward but also upward. Table 5 presents some summary statistics on the extent of DNWR and DRWR. We find real wage rigidity to be slightly higher than nominal wage rigidity in France (respectively $10.0 \%$ and $8.8 \%$ ). Cross-county comparisons indicate a lower degree of rigidity in France than in the Euro Area, where DRWR is found to be $20.3 \%$ and DNWR 9.3\% (see ECB, 2009). The same hierarchy is obtained with the use of the IWFP protocol (see Dickens et al., 2007) ${ }^{10}$. There are modest differences of the extent of wage rigidity across sectors in France. One exception is real wage rigidity in the trade sector due to the high share of people paid the minimum wage. However, there is a considerable variation across European countries in the extent of downward wage rigidity (see ECB, 2009). This suggests that labor market institutions rather than sector or technology are a source of heterogeneity of wage rigidity among European countries.

Table 4

Downward nominal and real rigidities (in \% of firms)

\begin{tabular}{lcc}
\hline \hline & DNRW & DRWR \\
\hline Total & 8.8 & 10.0 \\
Manufacturing & 9.4 & 9.6 \\
Trade & 9.3 & 20.4 \\
Business services & 8.3 & 9.9 \\
Personal services & 8.3 & 1.2 \\
\hline \hline
\end{tabular}

Source: WDN Survey.

WDN survey data also show that base wage cuts do occur: $2.5 \%$ of companies say they have used base wage cuts at least once in the past five years. Wage cuts are more frequent in the manufacturing sector. The data confirm the existence of downward adjustments in extreme cases. Managers are more likely to cut wages if the firm faces extreme financial difficulties or if jobs are at stake. Moreover, according to respondents these wage cuts affect $70 \%$ of employees within a company but not all.

10 Results of the WDN and IWFP are not comparable because the unit (firms vs. employees) and the type of data (cross-section vs. panel) are different. 


\subsection{Wage indexation}

Wage indexation directly affects downward wage rigidity. The degree of indexation is embedded in the labor market institutions. According to the law ${ }^{11}$, employment contracts in France do not have to automatically tie wages to a cost-of-living index with the exception of the minimum wage ${ }^{12}$. According to Koubi and Lhommeau (2006), the spillover effect of the minimum wage increase is on average $30 \%$ at the bottom of the wage scale with a high dispersion across sectors. The existence of a minimum wage implies that real wages become more rigid as inflation rate goes to zero.

The WDN survey provides information on both formal indexation of the minimum wage and informal practice of indexation (for instance at each round of collective bargaining). Results show that about one third of companies say they practise informal indexing. $22.4 \%$ of firms say they adopt backward-looking behavior and index their wages to past inflation (see Table 5). 9.3\% of firms adjust wages to expected inflation. However, the survey was conducted in an environment of inflation close to $2 \%$. It therefore does not reflect any change in behavior associated with a low inflation or a context of rising inflation. In the presence of inflationary pressures, wage pressures could be intensified, which in turn could increase the degree of wage indexation to inflation.

Table 5

Wage indexation (in \%)

\begin{tabular}{lccc}
\hline \hline & Link to past inflation & Link to expected inflation & Wage indexation \\
\hline Total & 22.4 & 9.3 & 31.7 \\
Manufacturing & 27.0 & 11.2 & 38.2 \\
Trade & 28.9 & 2.3 & 31.2 \\
Business services & 18.5 & 8.4 & 26.8 \\
Personal services & 1.6 & 1.6 & 3.2 \\
\hline \hline
\end{tabular}

Source: WDN Survey.

\subsection{Perceived reasons for wage stickiness}

We also assess potential reasons for wage rigidity. Evidence on this issue is rather scarce and dispersed. Direct information can be obtained from the WDN survey. It contains a question which directly addresses the reasons for wage stickiness (see Appendix 2). Possible answers to this question include a list of statements addressed in simple terms and based on sources of rigidities arising from institutional restrictions, insurance against negative shocks, relative wages (when taking wage decisions firms take into account wage rates set in other firms) and the efficiency-wage hypothesis. Four versions of the efficiency wage theory are detailed: the first one holds that high wages reduce labor turnover. The second efficiency-wage theory holds that the average quality of a firm's work force depends on the wage it pays its employees. The third and fourth versions of the efficiency-wage theory hold that high wages increase workers' effort and (respectively) reciprocity. Company responses have been converted into numerical scores ranging from 1 to 4 using the same coding scheme as the one proposed by Blinder et al. (1998) in their study of price rigidity. Above 2.5 , the score is considered as reasonably strong and an average above 3.0 as very strong. Table 7 ranks theories by mean scores.

Article L112-2, Code monétaire et financier.

12 The minimum wage is adjusted each July by an automatic indexation to the cost of living and half of increased purchasing power of average wage workers. Moreover, companies have incentives to increase wages at the bottom of the wage scale in order to maintain wage hierarchy. 
Table 6

Rating of theories explaining wage stickiness (mean scores)

\begin{tabular}{lcc}
\hline \hline & France & Europe $^{*}$ \\
\hline Shirking & 3.3 & 3.1 \\
Gift-exchange & 3.3 & 3.0 \\
Explicit contract & 3.1 & 2.9 \\
Adverse selection & 3.1 & 3.3 \\
Negative signal & 2.7 & 2.8 \\
Reputation & 2.5 & 2.6 \\
Relative wages & 2.2 & 2.6 \\
Turnover & 2.1 & 2.8 \\
Implicit contract & 1.6 & 2.4 \\
\hline \hline
\end{tabular}

Excluding Germany and Greece

Note: the theories are ranked according to the mean scores they received from 1 (not relevant) to 4 (very relevant).

Source: WDN Survey and ECB (2009) for EU economies (excluding Germany and Greece).

Data suggest that both the fairness and the shirking versions of the efficiency-wage hypothesis are supported. Overall, companies are reluctant to adjust wages. The survey results also indicate that lower wages would not be an incentive and this could lead to lower productivity per employee. The main reasons for deviations from the going rate appear to be employer-related, even in firms in which all workers are covered by collective agreements. We emphasize mechanisms of wage rigidity at the establishment level. When faced with shocks, firms use alternative ways to adjust.

\section{ADJUSTMENT IN THE PRESENCE OF WAGE RIGIDITY}

In the presence of downward of rigidity, the WDN survey provides information on a firm's adjustment. Respondents were asked to assess the relevance of the following adjustments margins: an increase in prices, a reduction in profit margins, a reduction in output and a reduction in costs. By asking firms how they respond to shocks, there is no need to identify the shocks themselves. The WDN survey specifies three hypothetical shock scenarios: a slowdown in demand, an increase in intermediate costs (e.g. an oil price increase) and a permanent rise in wages (for instance due to contracts bargained at the industry level). All these three shocks are considered as unexpected and common to all firms. We provide evidence on how firms react to shocks and distinguish different margins of adjustment.

\subsection{Responses to shocks}

Table 7 shows that companies use different strategies when faced with shocks combining price adjustment and costs minimization. The chosen margins of adjustments differ according to the type of shock. Companies reduce costs primarily when they are faced with a demand shock and increase prices when faced with supply shocks. Cost reduction is an important strategy after a demand shock (mean score of 3.1). By contrast, price adjustment is an important strategy for the respondents after a supply shock (mean score of 2.7 and 2.6). We do not find any sign of the potential price vs. quantity adjustment dichotomy (see Andersen and Toulemonde, 2004) since strategies of adjustment are mixed. 
Table 7

Economic shocks and margins of adjustment (average scores)

\begin{tabular}{lcccc}
\hline \multicolumn{1}{c}{ Average score } & Adjust prices & Reduce margins & Reduce output & Reduce costs \\
\hline Negative demand shock & 2.2 & 2.4 & 2.3 & 3.1 \\
Positive cost shock & 2.7 & 2.2 & 1.4 & 2.7 \\
Wage shock & 2.6 & 2.2 & 2.5 & 1.3 \\
\hline \hline
\end{tabular}

Note: average score received for each statement $(4=$ very relevant, $3=$ relevant, $2=$ little relevance, $1=$ irrelevant).

Source: WDN Survey.

We try to determine which factors increase the probability to change price, margin, output and cost. Three kinds of explanations are considered: the degree of market competition, the type of collective agreements and the technology of the firm. We use a measure of perceived competition at the firm level. Both firm-level and industry-level collective agreements are considered. Labor intensity identifies the technology of the firm. A set of control variables captures features of the firm's strategies: industry dummies to capture differences in technology arising from industry characteristics, geographical area, composition of the work force. We model determinants of firms' reaction to adverse shock jointly. This contributes to the survey literature on price or wage initiated by Blinder. We use a quadrivariate probit model to take into account the fact that decisions have been taken simultaneously. To allow for the possibility that choices are related to unobserved factors, error terms are correlated. The equations for this model have the following form:

$\begin{aligned} \text { Adjust price } & y_{1}= \begin{cases}1 & \text { if } X \beta+\varepsilon_{1}>0 \\ 0 & \text { otherwise }\end{cases} \\ \text { Reduce margin } & y_{2}= \begin{cases}1 & \text { if } Z \gamma+\varepsilon_{2}>0 \\ 0 & \text { otherwise }\end{cases} \\ \text { Reduce output } & y_{3}= \begin{cases}1 & \text { if } W \theta+\varepsilon_{3}>0 \\ 0 & \text { otherwise }\end{cases} \\ \text { Reduce cost } & y_{4}= \begin{cases}1 & \text { if } V \alpha+\varepsilon_{4}>0 \\ 0 & \text { otherwise }\end{cases} \end{aligned}$

We assume that the error terms are distributed as a quadrivariate normal distribution $\left(\varepsilon_{1}, \varepsilon_{2}, \varepsilon_{3}, \varepsilon_{4}\right) \rightarrow \mathrm{N}_{4}(0, \Sigma)$, where $\Sigma$ has values of 1 on the leading diagonal and correlations $\rho_{\mathrm{jk}}=\rho_{\mathrm{kj}}$ as off-diagonal elements. The log-likelihood function of the model is:

$$
l=\sum_{i=1}^{n} \log \Phi_{4}\left(\mu_{i}, \Omega\right)
$$

$\Phi_{4}\left(\mu_{\mathrm{i}}, \Omega\right)$ is the quadrivariate normal cdf where $\mu_{\mathrm{i}}=\left(\mathrm{q}_{1} \mathrm{X} \beta, \mathrm{q}_{2} \mathrm{Z} \gamma, \mathrm{q}_{3} \mathrm{~W} \theta, \mathrm{q}_{4} \mathrm{~V} \alpha\right) ; \Omega$ has elements $\Omega_{\mathrm{jj}}=1$ and $\Omega_{\mathrm{jk}}=\mathrm{q}_{\mathrm{j}} \mathrm{q}_{\mathrm{k}} \rho_{\mathrm{jk}}$ for $\mathrm{j}, \mathrm{k}=1, \ldots, 4$. The 'signs' variables $\left(\mathrm{q}_{\mathrm{k}}=2 \mathrm{y}_{\mathrm{k}-1}\right)$ being equal to 1 and -1 depending on whether the observed binary outcome equals 1 or 0 for $\mathrm{k}=1, \ldots, 4$.

The likelihood function requires evaluation of quadrivariate normal distribution. For high dimension of the multivariate normal distribution, simulation-based methods are required. Here, we use simulated ML based on the 'GHK' simulator. The GHK simulator exploits the fact that a multivariate normal distribution can be expressed as the product of sequential conditioned univariate normal distributions. The simulated probabilities are plugged into the likelihood at each iteration of the maximization. Table 8 reports multivariate probit estimations ${ }^{13}$. The first

13 The estimation has been performed using the mvprobit Stata program by Cappellari and Jenkins (2003). 
column gives the likelihood of the respective reaction after a demand shock, the second and third columns refer to the response after an increase in the cost of an intermediate input or the labor cost.

Table 8

Multivariate probit estimates

\begin{tabular}{cccccc}
\multicolumn{2}{c}{ Demand shock } & \multicolumn{2}{c}{ Cost shock } & \multicolumn{2}{c}{ Labor cost shock } \\
Coeff. & $\begin{array}{c}\text { Rob. } \\
\text { std. }\end{array}$ & Coeff. & $\begin{array}{c}\text { Rob. } \\
\text { std. }\end{array}$ & Coeff. & $\begin{array}{c}\text { Rob. } \\
\text { std. }\end{array}$ \\
\hline
\end{tabular}

\section{Price adjustment equation}

Fierce competition

Strong competition

Weak competition

No competition

Collective agreement. industry level

Collective agreement. firm level

Labor intensity

Maufacturing

Trade

Business services

Personnal services

\section{Margin adjustment equation}

Fierce competition

Strong competition

Weak competition

No competition

Collective agreement. industry level

Collective agreement. firm level

Labor intensity

Maufacturing

Trade

Business services

Personnal services

\section{Output adjustment equation}

Fierce competition

Strong competition

Weak competition

No competition

Collective agreement. industry level

Collective agreement. firm level ref.

$$
-0.35^{* * *}
$$

0.12

$-0.65^{* * *}$

0.13

$-0.56^{* * *}$

0.25

0.06

0.30

$-0.20^{* *}$

0.08

$-0.43$

0.24

ref.

$-0.36$

0.26

0.07

0.12

$-0.04^{* * *}$

0.00

ref.

$0.25^{* *}$

0.12

$0.43^{* * *}$

0.13

0.21

0.21

$-0.18$

0.39

$-0.04$

0.09

$-0.38$

0.25

ref.

$-0.16$

0.56

$-0.17^{*}$

0.12

$-0.57^{* * *}$

0.24

ref.

$-0.32^{* *}$

0.12

$-0.11$

0.12

ref.

$-0.57^{* * *}$

0.13

$-0.58^{* * *}$

0.12

$-0.57^{* * *}$

0.22

$-0.57$

0.36

0.03

0.08

0.24

0.24

0.37

ref.

0.25

$-0.03$

0.24

$-0.17$

0.12

$-0.05^{* * *}$

0.00

ref.

$-0.24^{* *}$

0.12

$-0.74^{* * *}$

0.13

$-1.04^{* * *}$

0.23

$-0.30$

0.35

$-0.06$

0.09

0.30

0.25

ref.

0.05

0.24

0.12

$-0.23^{*}$

0.12

$-0.04^{* * *}$

0.00

$-0.05^{* * *}$

0.01

\subsection{3}

0.21

0.39

0.09

0.24

0.12

0.65

\section{西}




\begin{tabular}{lcccccc}
\hline Labor intensity & -0.30 & 0.24 & $0.51^{*}$ & 0.30 & $-0.46^{*}$ & 0.25 \\
Maufacturing & ref. & & ref. & & ref. & \\
Trade & -0.06 & 0.29 & 0.19 & 0.31 & 0.34 & 0.29 \\
Business services & $-0.41^{* * *}$ & 0.12 & $-0.27^{*}$ & 0.15 & $-0.41^{* * *}$ & 0.12 \\
Personnal services & $0.04^{* * *}$ & 0.00 & $-0.04^{* * *}$ & 0.00 & 0.00 & 0.59
\end{tabular}

\section{Cost adjustment equation}

\begin{tabular}{lcccccc} 
Fierce competition & ref. & \multicolumn{3}{c}{ ref. } & ref. & \\
Strong competition & 0.05 & 0.13 & -0.02 & 0.15 & -0.20 & 0.14 \\
Weak competition & 0.11 & 0.14 & -0.01 & 0.15 & -0.06 & 0.15 \\
No competition & -0.08 & 0.22 & -0.57 & 0.35 & 0.01 & 0.27 \\
Collective agreement. industry level & 0.48 & 0.32 & 0.33 & 0.35 & -0.57 & 0.42 \\
Collective agreement. firm level & 0.04 & 0.09 & 0.01 & 0.09 & -0.02 & 0.11 \\
Labor intensity & -0.39 & 0.26 & -0.15 & 0.25 & -0.43 & 0.31 \\
Maufacturing & ref. & & ref. & & ref. & \\
Trade & 0.13 & 0.29 & 0.26 & 0.29 & -0.18 & 0.33 \\
Business services & $0.19^{* * *}$ & 0.12 & $-0.28^{* * *}$ & 0.12 & $-0.33^{* *}$ & 0.15 \\
Personnal services & $0.37^{* * *}$ & 0.27 & $0.66^{* * *}$ & 0.27 & $-0.04^{* * *}$ & 0.00 \\
Not reported : intercept. sector. size area dummies. & export share. assessment & & & \\
Observations & 1307 & & 1350 & & 1113 & \\
Log-likelihood & -2628 & & -2250 & & -2226 & \\
rho21 & $0.47^{* * *}$ & 0.03 & $-0.12^{* * *}$ & 0.04 & $-0.08^{* * *}$ & 0.04 \\
rho31 & $-0.13 * * *$ & 0.04 & -0.01 & 0.05 & 0.00 & 0.04 \\
rho41 & -0.06 & 0.04 & 0.01 & 0.04 & $0.10^{* * *}$ & 0.05 \\
rho32 & $-0.12 * * *$ & 0.04 & $0.21^{* * *}$ & 0.05 & $0.17^{* * *}$ & 0.04 \\
rho42 & -0.01 & 0.04 & $0.11^{* * *}$ & 0.04 & 0.06 & 0.05 \\
rho43 & $0.11 * * *$ & 0.04 & $0.14^{* * *}$ & 0.04 & $0.16^{* * *}$ & 0.05 \\
\hline
\end{tabular}

The nature of the response might depend on the characteristics of the firm (size, sector, area) and the conditions external to the firm (wage bargaining system, competition and technology). The intensity of competition amplifies company responses. Our empirical results show that stronger competition is associated with more intensive adjustment in the aftermath of shocks. Price increases (decreases) after supply (demand) shocks are less (more) likely when competition in the product market is strong. Higher labor cost share lowers the likelihood of price increases after a shock. Since a higher labor share implies that marginal costs are more sensitive to labor costs, prices are more likely to be raised in response to a general wage increase. This is also consistent with the evidence coming from the price stickiness literature (see Loupias and Sevestre, 2013). Our results also suggest that collective bargaining at sectoral level does not have any significant impact on the probability that firms will adjust. There is a clear sectoral effect indicating that, compared to the manufacturing sector, firms operating in the market services sector are less likely to adjust. We also find that large firms are less likely to adjust. However, there might be a strong interaction of demand shocks and the degree of competition. Competition makes prices 
react more to demand changes than to costs changes. Finally, the error terms are found to be significantly correlated.

An important question is whether the difference in response to shocks across countries might be explained by the differences between job market institutions. In a study involving the twelve European countries participating in the WDN survey, Bertola et al. (2012) find evidence of important institutional influences on company-level responses to all types of shocks. Collective pay agreements bargained outside the firm increase the probability that firms cut costs by laying off workers, while strict employment protection legislation increases the likelihood that firms reduce wages. The effect of collective agreement is more prevalent when we use the European dataset (due to heterogeneity) than in a single country case (see above). Across the euro area countries, more stringent employment protection is associated with a lower probability of employment reduction in response to a shock. Countries with rather stringent employment protection, which is the case of France, tend to smooth permanent employment adjustment, while increasing the responsiveness of hours adjustment and (less clearly) of temporary employment.

\subsection{Wages of new hires}

In the presence of downward wage rigidity, firms have other ways to adjust labor costs. Surveyed firms were asked whether they had ever used other adjustment mechanisms to reduce labor costs. These mechanisms include the hiring of new employees at a lower wage level than ongoing wages, slowing down the rate at which promotions are filled or reducing bonuses and non-pay benefits. Evidence in the literature on wages of new hires shows procyclicality of real wages (more than job stayers) in the United States (see Beaudry and DiNardo, 1991); this is true for both workers moving from job to job and those moving from unemployment to job (see Bils, 1985). In the United Kingdom, Germany and Italy, there is no evidence that wages of movers are more pro-cyclical than wages of stayers (see Peng and Siebert, 2007). On the contrary, Carneiro et al. (2008) find a significant wage cyclicality of new hires taking into account firms and employees unobserved heterogeneity in Portugal. Evidence is scarce on this issue in France. Traditional interpretation of wage movers stresses a cyclical composition effect of jobs: during recessions firms hire more skilled workers than during booms. It also relies on inter-industry wage differentials. If these sectors are cyclically sensitive, workers can switch into high-paying jobs during booms. A more recent interpretation insists on a 'cyclical within firm' effect according to which wages of new hires are more flexible than wages of existing employees (see Pissarides, 2009). The WDN survey provides direct evidence on the main occupational group within the firm.

In response to idiosyncratic shocks, half of the companies say that new employees are hired with lower wages. However, under normal circumstances, wages of new hires are determined largely by the pay scale. In this context, deviations from the going rate are not very common. The survey also points out that wages of new hires remain determined by the pay scale within companies. Recruiters try to understand how new hires fit into the wage scale given their training experience, skills and jobs. As pointed by Bewley (1999), pay scales allow guaranteeing fairness among employees (as suggested in Section 5).

\section{CONCLUSIONS}

Using a source of a qualitative nature, this study highlights several characteristics of wagesetting in France. First, a vast majority of companies change wages each year. Changes in wages occur at regular intervals during the year and are concentrated in January and in July.

As in previous research, we find evidence of the existence of downward wage rigidity. Our results suggest that downward real wage rigidity is slightly higher than nominal wage rigidity 
in France but lower than the European average. Among explanations advocated in the literature for wage rigidity, both the fairness and the effort versions of the efficiency-wage hypothesis are important considerations for French firms.

About one third of companies have an internal wage-setting policy linking wages to inflation. When companies are faced with adverse shocks, they use mixed strategies combining prices adjustment and costs minimization. Only a partial response to economic shocks is transmitted into prices. Companies generally adopt cost-cutting strategies. In the presence of downward base wage rigidity, companies use different strategies such as reductions in bonuses or wages of new hires and early retirement schemes. The choice of strategies depends on the firms' characteristics. Large firms in the service sector are less likely to adjust. The wage of new hires also plays an important role in this adjustment.

A number of questions for future work remains open. First, do these results remain unchanged in a context of low inflation or rising inflation? Another key question is to know how asymmetry of shocks matters as the questionnaire focuses on adverse shocks.

\section{Acknowledgements}

The views expressed in this paper are solely the responsibility of the authors and should not be interpreted as reflecting the views of the Banque de France.

\section{References}

Andersen T.M., Toulemonde E. (2004) Adapting Prices or Quantities in the Presence of Adjustment Costs?, Journal of Money, Credit and Banking Vol. 36(2), pp. 177-196. Blackwell Publishing.

Agell J., Bennmarker H. (2005) Wage incentives and wage rigidity: a representative view from within, Labour Economics Vol. 14, n ${ }^{\circ}$ 3, pp. 347-369.

Akerlof G.A., Dickens W.T., Perry G.L. (1996) The Macroeconomics of Low Inflation, Brookings Papers on Economic Activity, pp. 1-76.

Altonji P., Devereux P. (2000) Is There Nominal Wage Rigidity? Evidence from Panel Data., Research in Labor Economics Vol. 19, Elsevier Science Inc.: pp. 383-431.

Amirault D., Fenton P., Laflèche T. (2013) Asking about Wages: Results from the Bank of Canada's Wage Setting Survey of Canadian Companies. Bank of Canada.

Ariga K., Kambayashi R. (2010) Employment and wage adjustments at firms under distress in Japan: An analysis based upon a survey, Journal of the Japanese and International Economies 24(2), pp. 213-235.

Avouyi-Dovi S., Fougère D., Gautier E. (2013) Wage rigidity, collective bargaining, and the minimum wage: evidence from French agreement data, Review of Economics and Statistics 95(4), pp. 1337-1351.

Babecký J., Du Caju P., Kosma T., Lawless M., Messina J., Rõõm T. (2012) How do European firms adjust their labour costs when nominal wages are rigid?, Labour Economics 19(5), pp. 792-801.

Barattieri A., Basu S., Gottschalk P. (2014) Some Evidence on the Importance of Sticky Wages, American Economic Journal: Macroeconomics 6(1), pp. 70-101.

Beaudry P., DiNardo J.E. (1991) Implicit Contracts and the Movement of Wages over the Business Cycle, Journal of Political Economy, August 1991.

Bertola G., Dabusinskas A., Hoeberichts M., Izquierdo M., Kwapil C., Montornès J., Radowski D. (2012) Price, wage and employment response to shocks: Evidence from the WDN Survey, Labour Economics 19(5), pp. 783-791

Bewley T.F. (1999) Why Wages Don’t Fall During A Recession, Cambridge, Mass.: Harvard University Press.

Bils M.J. (1985) Real Wages over the Business Cycle: Evidence from Panel Data, Journal of Political Economy Vol. 93(4), pp. 666-689, August. University of Chicago Press.

Birscoup P., Dessy O., Fourcade N. (2005) Les salaires sont-ils rigides? Le cas de la France à la fin des années 1990, Économie et Statistique n ${ }^{\circ} 386$.

Blinder A., Canetti E., Lebow D., Rudd J. (1998) Asking about prices: a new approach to understand price stickiness, New York: Russel Sage Foundation. 
Blinder A., Choi D.H. (1990) A Shred of Evidence on Theories of Wage Stickiness, The Quarterly Journal of Economics 105, pp. 1003-1015.

Cahuc P., Zylberberg A. (2004) Labour economics, MIT Press, 872 p.

Campbell C.M., Kamlani K.S. (1997) The Reasons for Wage Rigidity: Evidence from a Survey of Firms, The Quarterly Journal of Economics 3, pp. 759-789.

Card D., Hyslop D. (1997) Does Inflation Grease the Wheels of the Labor Market?, in: Romer, C.D., Romer, D.H. (Eds.), Reducing Inflation: Motivation and Strategy. Chicago: The University of Chicago Press, pp. 71-114.

Cardoso A.R., Portugal P. (2005) Contractual Wages and the Wage Cushion under Different Bargaining Settings, Journal of Labor Economics Vol. 23, Issue 4.

Carneiro A., Portugal P. (2008) Workers' Flows and Real Wage Cyclicality, Mimeo, European Central Bank.

Cappellari, L., Jenkins S.P. Multivariate probit regression using simulated maximum likelihood, Stata Journal 3.3 (2003), pp. 278-294.

Christiano L.J., Eichenbaum M., Evans C. (2005) Nominal Rigidities and the Dynamic Effects of a Shock to Monetary Policy, Journal of Political Economy 113(1), pp. 1-45.

Dickens W., Goette L., Groshen E.L., Holden S., Messina J., Schweitzer M.E., Turunen J., Ward M. (2007) How Wages Change: Micro Evidence from the International Wage Flexibility Project, Journal of Economic Perspectives 21(2), pp. 195-214.

Druant M., Du Caju P., Delhez P. (2008) Results of the Bank's survey of wage-setting in Belgian firms, Economic Review (III), pp. 49-73.

Druant M., Fabiani S., Kezdi G., Lamo A., Martins F., Sabbatini R. (2012) Firms' price and wage adjustment in Europe: Survey evidence on nominal stickiness, Labour Economics 19(5), pp. 772-782.

Du Caju Ph., Gautier E., Momferatou D., Ward-Warmedinger M. (2008) Institutional features of wage bargaining in 22 EU countries, the US and Japan, Ekonomia 12 (2), pp. 57-108.

Erceg C.J., Henderson D.W., Levin, A.T. (2000) Optimal monetary policy with staggered wage and price contracts, Journal of Monetary Economics 46(2), pp. 281-313.

European Central Bank (2009) Wage dynamics in Europe: Final report of the Wage Dynamics Network (WDN). Directorate General Research. December.

Fehr E., Goette L. (2005) Robustness and real consequences of nominal wage rigidity, Journal of Monetary Economics $52(4)$, pp. 779-804.

Franz W., Pfeiffer F. (2006) Reasons for Wage Rigidity in Germany, Labour-Review of Labour Economics and Industrial Relations 20 (2), pp. 255-284.

Galuscak K., Murphy A., Nicolitsas D., Smets F., Strzelecki P., Vodopivec M. (2012) The determination of wages of newly hired employees: Survey evidence on internal versus external factors, Labour Economics 19 (5), pp. 802-812.

Gertler M., Sala L., Trigari A. (2008) An Estimated Monetary DSGE Model with Unemployment and Staggered Nominal Wage Bargaining, Journal of Money, Credit and Banking 40, pp. 1713-1764.

Gottschalk P. (2005) Downward Nominal Wage Flexibility: Real or Measurement Error?, The Review of Economics and Statistics 87(3), pp. 556-568.

Kim J., Ruge-Murcia F.J. (2011) Monetary policy when wages are downwardly rigid: Friedman meets Tobin, Journal of Economic Dynamics and Control 35(12), pp. 2064-2077.

Koubi M., Lhommeau B. (2006) La revalorisation du smic et ses effets de diffusion dans l'échelle des salaires sur la période 2000-2005, Dares, Premières synthèses.

Kramarz F. (2001) Rigid Wages: What Have we Learnt from Microeconometric Studies, in: Drèze, J. (Ed.), Advances in Macroeconomic Theory. Oxford University Press, Oxford, UK, pp. 194-216.

Le Bihan H., Montornès J., Heckel T. (2012) Sticky wages: evidence from quarterly microeconomic data, American Economic Journal: Macroeconomics 4(3), pp. 1-32.

Lebow D.E., Saks R.E., Wilson B.A. (2003) Downward Nominal Wage Rigidity: Evidence from the Employment Cost Index, Advances in Macroeconomics Vol. 3, Issue 1, Article 2.

Levin A.T., Onatski A., Williams J., Williams, N.M. (2006) Monetary policy under uncertainty in micro-founded macroeconometric models, in: NBER Macroeconomics Annual 2005 Volume 20 (pp. 229-312). MIT Press.

Loupias C., Sevestre P. (2013) Costs, demand, and producer price changes, Review of Economics and Statistics 95(1), pp. 315-327.

McCallum A, Smets F. (2010) Real wages and monetary policy transmission in the euro area. Kiel Working Papers, 1360.

Messina J., Du Caju P., Duarte C., Izquierdo M., Hansen N. (2008) The Causes and Consequences of Nominal and Real Wage Rigidity: a Sectoral Approach Mimeo, European Central Bank.

Olivei G., Tenreyro S. (2010) Wage-setting patterns and monetary policy: International evidence, Journal of Monetary Economics 57 (7), pp. 785-802.

Palenzuela D.R., Jimeno J.F. (1996) Wage drift in collective bargaining at the firm level, Annales d'Economie et de Statistique $n^{\circ} 41 / 42$. 
Peng F., Siebert W.S. (2007) Real Wage Cyclicality in Germany and the UK: New Results Using Panel Data, IZA Discussion Papers $n^{\circ} 2688$, Institute for the Study of Labor.

Pissarides C.A. (2009) The Unemployment Volatility Puzzle: Is Wage Stickiness the Answer?, Econometrica 2009 Vol. 77, issue 5, pp. 1339-1369.

Schmitt-Grohé S., Uribe M. (2013) Downward Nominal Wage Rigidity and the Case for Temporary Inflation in the Eurozone, The Journal of Economic Perspectives 27(3), pp. 193-211.

Smets F., Wouters R. (2003) An estimated dynamic stochastic general equilibrium model of the euro area, Journal of the European economic association 1(5), pp. 1123-1175.

Taylor J.B. (1980) Aggregate Dynamics and Staggered Contracts, Journal of Political Economy Vol. 88 (1), pp. 1-23.

Tobin J. (1972) Inflation and Unemployment, American Economic Review 62, pp. 1-18.

Zoega G., Karlssonn T. (2005) Does wage compression explain rigid money wages?, Economics Letters Vol. 93, Issue 1, October 2006, pp. 111-115.

\section{APPENDIX 1}

\section{Description of the survey}

The WDN survey that was carried out during the fall of 2007 is an ad-hoc survey. The questionnaire covered among other topics wage changes, adjustment to shocks, and adjustment to inflation.

\section{Scope of the survey}

The WDN survey was conducted among a sample of companies usually interviewed for the purpose of the Banque de France monthly Business Survey. It was carried out in close collaboration with the Banque de France's branches. The survey covers companies with at least 5 employees and whose economic activity belong to the sectors $\mathrm{C}$ to $\mathrm{K}$ of the classification of activities of the European Community (manufacturing, trade, hotels and restaurants, market services) in France. The sectors covered by the sample represent approximately $69 \%$ of total GDP. The survey focuses on employees and excludes apprentices and trainees. The sample does not include the civil servants and self-employed. A harmonized survey was conducted simultaneously in 16 European countries. Some specific questions were added to the core questionnaire concerning wage drift and in order to take into account some institutional specificities.

The data collected relate to the year 2007. The questionnaire focuses, unless otherwise stated, on the base wage excluding overtime pay and bonuses. Questions relative to the firms' wage policy are mostly qualitative. The survey also collects information about the firm, on the flows of entries and exits of employees within firms. Companies were mainly interviewed by mail and electronic mail but also by face to face or telephone interviews.

\section{Survey methodology}

The basic statistical unit is the firm. Groups are not interviewed as such, the results are not consolidated. 6645 firms were interviewed. The questionnaire was mainly filled by business managers (CEO, CFO or human resources manager). The response rates achieved in WDN surveys for European countries are low due to the length and the complexity of the questionnaire. Details of response rate by sector, size and geographical area are presented in Table A. 
Table A

The sample (in \%)

\begin{tabular}{|c|c|c|c|c|}
\hline & $\begin{array}{l}\text { Firms in the } \\
\text { initial sample }\end{array}$ & Respondents & Response rate & Employees \\
\hline \multicolumn{5}{|l|}{ Sector } \\
\hline Manufacturing & 3816 & 1295 & 33.9 & 374612 \\
\hline Trade & 262 & 63 & 24.0 & 4976 \\
\hline Market services & 2394 & 653 & 27.3 & 116771 \\
\hline Non-market services & 73 & 18 & 24.7 & 975 \\
\hline \multicolumn{5}{|l|}{ Size } \\
\hline 0-19 employees & 1257 & 281 & 22.4 & 2500 \\
\hline 20-49 employees & 1236 & 396 & 32.0 & 11510 \\
\hline 50-199 employees & 2192 & 764 & 34.9 & 71908 \\
\hline >200 employees & 1860 & 588 & 31.6 & 411416 \\
\hline \multicolumn{5}{|l|}{ Geographical area } \\
\hline Paris area & 772 & 178 & 23.1 & 69824 \\
\hline North East & 1795 & 589 & 32.8 & 135436 \\
\hline North West & 1428 & 431 & 30.2 & 104949 \\
\hline South East & 1529 & 454 & 29.7 & 97644 \\
\hline South West & 1021 & 377 & 36.9 & 89481 \\
\hline Total & 6545 & 2029 & 31.0 & 497334 \\
\hline
\end{tabular}

The descriptive results are weighted. For a given firm, weights indicate the number of workers in relation to the total population, taking into account the firm's size and sector. The weight is defined as the sum of all employees in the stratum divided by the number of firms in that stratum. The sample is divided into 20 strata according to the sector and the number of employees. The weights were derived from the business register (Sirene) and probability of sampling. The sample weights take no account of the classification of the employees according to the occupational status. 